\title{
Regional Investment Attractiveness's Model Analysis at the Heart of Russian Investment Policy
}

\author{
Evgenii Mitrofanov ${ }^{1, *}$, Alevtina Kulagina ${ }^{2}$, and Liya Panferova ${ }^{2}$ \\ ${ }^{1}$ Moscow State University of Humanities and Economics, RU-107150, Moscow, Russia \\ ${ }^{2}$ I.N. Ulyanov Chuvash State University, RU-428015, Cheboksary, Russia
}

\begin{abstract}
The article analyzes the investment attractiveness of regions of the Volga Federal District in the Russian Federation using the principal component method. Indicators are selected characterizing investment attractiveness of Russian regions of the Volga Federal District. Functional dependence of the selected indicators are defined, based on which the estimation of level of investment appeal of regions of the Volga Federal District and their clustering. Recommendations for improving the investment policy of Russian regions are given.
\end{abstract}

\section{Introduction}

In modern economic conditions, one of the key points of Russia's investment policy is to attract investment in the competition in the global financial market and increase the level of investment attractiveness of the country's regions [1-5]. Determining the level of investment attractiveness of a country and its regions is widely used by potential investors in their activities, which helps to identify weaknesses in investment policy and investment prospects both in an individual subject and in the country as a whole, and also helps to identify factors that affect the country's investment policy and investment attractiveness of subjects, and the need to develop new and improve existing methods for assessing the investment attractiveness of regions of the country [3,5].

Many researchers agree that the investment attractiveness of a region is an integral characteristic of the investment object, which reflects the subjective relationship between the investor and the investment object, i.e. how well the investment object meets the investor's goals. Investment attractiveness includes investment potential and investment risk. In turn, they are divided into a number of indicators. Thus, investment attractiveness is determined by many factors that can be combined in meaning $[1,2,4]$.

\section{Results and discussion}

Many existing methods of analyzing investment attractiveness are usually related to factor analysis. Therefore, in this study, we will use the principal component method to assess the level of investment attractiveness of regions.

The principal component method is used to decrease the number of variables and construct generalized factors, i.e. principal components that are uncorrelated with each other.

At the first stage of statistical analysis, it is necessary to determine a set of initial indicators that best characterize the objects under study in terms of their investment attractiveness. We selected 15 most significant indicators (table 1).

Table 1. Grouping of indicators used to analyze region's investment attractiveness

\begin{tabular}{|c|c|}
\hline $\begin{array}{c}\text { Composite } \\
\text { indicator }\end{array}$ & Group indicators \\
\hline $\begin{array}{c}\text { Production group } \\
\text { of indicators }\end{array}$ & $x_{1}$-GRP per capita, RUB \\
\cline { 2 - 2 } & $\begin{array}{c}x_{2} \text { - Industrial production index, \% of } \\
\text { the previous year }\end{array}$ \\
\hline $\begin{array}{c}\text { Financial and } \\
\text { economic group of } \\
\text { indicators }\end{array}$ & $\begin{array}{c}x_{3} \text { - The balanced financial result of } \\
\text { activity of organizations, mln. RUB. }\end{array}$ \\
\cline { 2 - 2 } & $\begin{array}{c}x_{4} \text { - Share of unprofitable } \\
\text { organizations, in \% of the total } \\
\text { number of organizations }\end{array}$ \\
\cline { 2 - 2 } $\begin{array}{c}\text { The employment } \\
\text { group of indicators }\end{array}$ & $\begin{array}{c}x_{5} \text { - Investment in fixed assets per } \\
\text { capita, RUB }\end{array}$ \\
\cline { 2 - 2 } & $\begin{array}{c}x_{7}-\text { The level of labor productivity in } \\
\text { the region (the ratio of GRP to the } \\
\text { number of employees), \% }\end{array}$ \\
\hline $\begin{array}{c}\text { Innovative } \\
\text { (informational) } \\
\text { group of indicators }\end{array}$ & $\begin{array}{c}x_{8} \text {-Innovative activity of } \\
\text { organizations, \% }\end{array}$ \\
\cline { 2 - 2 } & $\begin{array}{c}x_{9} \text { - Percentage of the working } \\
\text { population engaged in research and } \\
\text { development, people }\end{array}$ \\
\hline $\begin{array}{c}\text { Infrastructure } \\
\text { group of indicators }\end{array}$ & $\begin{array}{c}x_{10} \text { - Retail trade turnover per capita, } \\
\text { RUB }\end{array}$ \\
\cline { 2 - 2 } & $\begin{array}{c}x_{11}-\text { Volume of paid services per } \\
\text { capita, RUB }\end{array}$ \\
\hline
\end{tabular}




\begin{tabular}{|c|c|}
\hline $\begin{array}{c}\text { Composite } \\
\text { indicator }\end{array}$ & Group indicators \\
\hline $\begin{array}{c}\text { Social group of } \\
\text { indicators }\end{array}$ & $\begin{array}{c}x_{12} \text { - The share of the population with } \\
\text { monetary incomes below the } \\
\text { subsistence minimum, in \% of the } \\
\text { total population }\end{array}$ \\
\cline { 2 - 2 } & $\begin{array}{c}x_{13} \text { - The ratio of per capita income to } \\
\text { the subsistence minimum, \% }\end{array}$ \\
\hline $\begin{array}{c}\text { Consumer group of } \\
\text { indicators }\end{array}$ & $\begin{array}{c}x_{14} \text { - Number of own passenger cars } \\
\text { per 1000 people. population, PCs. }\end{array}$ \\
\cline { 2 - 2 } & $\begin{array}{c}x_{15}-\text { Total area of residential } \\
\text { premises per inhabitant on average, } \\
\text { sq. m. }\end{array}$ \\
\hline
\end{tabular}

Factor analysis is performed using the Statistica application software package. To identify the presence of hidden relationships between indicators, we will find a matrix of paired correlations (table 2). The presence of values exceeding 0,7 in absolute value indicates that there is a relationship between the initial indicators.

Table 2. Correlation coefficient

\begin{tabular}{|c|c|c|c|c|c|c|}
\hline & $x_{1}$ & $x_{2}$ & $x_{3}$ & $x_{4}$ & $x_{5}$ & $x_{6}$ \\
\hline$x_{1}$ & 1 & & & & & \\
\hline$x_{2}$ & $-0,15$ & 1 & & & & \\
\hline$x_{3}$ & 0,87 & 0,06 & 1 & & & \\
\hline$x_{4}$ & 0,19 & $-0,18$ & $\begin{array}{l}-0,08 \\
\end{array}$ & 1 & & \\
\hline$x_{5}$ & 0,99 & $-0,18$ & 0,83 & 0,09 & 1 & \\
\hline$x_{6}$ & 0,97 & $-0,01$ & 0,90 & 0,06 & 0,96 & 1 \\
\hline$x_{7}$ & 0,93 & 0,21 & 0,87 & 0,13 & 0,91 & 0,96 \\
\hline$x_{8}$ & $-0,71$ & 0,05 & $-0,73$ & $-0,47$ & $-0,63$ & $-0,70$ \\
\hline$x_{9}$ & $-0,91$ & 0,25 & $-0,73$ & $-0,13$ & $-0,90$ & $-0,83$ \\
\hline $\begin{array}{c}x_{1} \\
0\end{array}$ & 0,99 & $-0,19$ & 0,80 & 0,20 & 0,99 & 0,95 \\
\hline $\begin{array}{c}x_{1} \\
1\end{array}$ & 0,99 & $-0,20$ & 0,81 & 0,23 & 0,98 & 0,93 \\
\hline $\begin{array}{c}x_{1} \\
2\end{array}$ & $-0,74$ & 0,14 & $-0,62$ & 0,35 & $-0,81$ & $-0,73$ \\
\hline $\begin{array}{c}x_{1} \\
3\end{array}$ & 0,35 & $-0,10$ & 0,20 & $-0,26$ & 0,45 & 0,40 \\
\hline $\begin{array}{c}x_{1} \\
4\end{array}$ & 0,99 & $-0,19$ & 0,81 & 0,24 & 0,98 & 0,95 \\
\hline $\begin{array}{c}x_{1} \\
5\end{array}$ & 0,99 & $-0,17$ & 0,85 & 0,26 & 0,96 & 0,94 \\
\hline
\end{tabular}

Table 2. Correlation coefficient (continuation)

\begin{tabular}{|c|c|c|c|c|c|}
\hline & $x_{7}$ & $x_{8}$ & $x_{9}$ & $x_{10}$ & $x_{11}$ \\
\hline$x_{1}$ & & & & & \\
\hline$x_{2}$ & & & & & \\
\hline$x_{3}$ & & & & & \\
\hline$x_{4}$ & & & & & \\
\hline$x_{5}$ & & & & & \\
\hline$x_{6}$ & & & & & \\
\hline$x_{7}$ & 1 & & & & \\
\hline$x_{8}$ & $-0,72$ & 1 & & & \\
\hline$x_{9}$ & $-0,76$ & 0,49 & 1 & & \\
\hline$x_{10}$ & 0,90 & $-0,65$ & $-0,93$ & 1 & \\
\hline$x_{11}$ & 0,89 & $-0,66$ & $-0,94$ & 1,00 & 1 \\
\hline$x_{12}$ & $-0,64$ & 0,13 & 0,81 & $-0,78$ & $-0,77$ \\
\hline$x_{13}$ & 0,29 & 0,21 & $-0,34$ & 0,42 & 0,39 \\
\hline$x_{14}$ & 0,90 & $-0,71$ & $-0,92$ & 0,99 & 0,99 \\
\hline$x_{15}$ & 0,90 & $-0,73$ & $-0,93$ & 0,98 & 0,99 \\
\hline
\end{tabular}

Table 2. Correlation coefficient (continuation)

\begin{tabular}{|c|c|c|c|c|}
\hline & $x_{12}$ & $x_{13}$ & $x_{14}$ & $x_{15}$ \\
\hline$x_{1}$ & & & & \\
\hline$x_{2}$ & & & & \\
\hline$x_{3}$ & & & & \\
\hline$x_{4}$ & & & & \\
\hline$x_{5}$ & & & & \\
\hline$x_{6}$ & & & & \\
\hline$x_{7}$ & & & & \\
\hline$x_{8}$ & & & & \\
\hline$x_{9}$ & & & & \\
\hline$x_{10}$ & & & & \\
\hline$x_{11}$ & & & & \\
\hline$x_{12}$ & 1 & & & \\
\hline$x_{13}$ & $-0,66$ & 1 & & \\
\hline$x_{14}$ & $-0,73$ & 0,35 & 1 & \\
\hline$x_{15}$ & $-0,71$ & 0,31 & 0,99 & 1 \\
\hline
\end{tabular}

We will check the validity of the principal component method and the significance of the correlation matrix using Wilkes test. Let's formulate hypotheses:

$H_{0}$ - the correlation matrix is insignificant;

$\mathrm{H}_{1}$ - the correlation matrix is significant.

Calculate the observed value of the criterion using the formula:

$$
\begin{gathered}
X_{\text {obs }}^{2}=-\left(n-\frac{1}{6}(2 m+5)\right) \ln (\operatorname{det} R)=-(11- \\
\left.\frac{1}{6}(2 \cdot 15+5)\right) \ln \left(1,73 \cdot 10^{-8}\right)=92,33
\end{gathered}
$$

The critical value is found in the Pearson distribution table $\boldsymbol{X}_{\boldsymbol{o b s}}^{\mathbf{2}}=\boldsymbol{X}_{\mathbf{0}, \mathbf{0 5} ; \mathbf{1 0 5}}^{\mathbf{2}}=\mathbf{8 2}, \mathbf{3 5}$, with significance level 0,05 and the value of the degree of freedom equal to $\frac{1}{2} \mathbf{m}(\mathbf{m}-1)=\frac{1}{2} \cdot 15 \cdot(15-1)=105$.

Thus $\boldsymbol{X}_{\mathbf{o b s}}^{\mathbf{2}}=\boldsymbol{X}_{\text {crit }}^{\mathbf{2}}$, therefore the main hypothesis is rejected in favor of the competing one $H_{1}$. The found matrix of paired correlations is significant at the significance level of 0,05 , i.e. there are hidden connections between the initial features and the use of the principal component method is justified.

The next stage of analysis involves decreasing the dimension of factors. We need to understand how many main components we need to allocate. This can be determined using the Kaiser and scree criteria. The Kaiser criterion selects factors with eigenvalues equal to or greater than 1 . According to this criterion, in our case, it is necessary to select 3 factors. According to scree criterion, after the fourth main component, the eigenvalues slow down, so it is worth selecting 4 main components.

On the basis of these criteria, it was decided to limit ourselves to three main components, which account for $92.1 \%$ of the total variance (table 3 ).

Table 3. Eigenvalues and relative contribution to the total variance

\begin{tabular}{|c|c|c|c|c|}
\hline № & Eigenvalue & $\begin{array}{c}\text { \% } \\
\text { of the total } \\
\text { variance }\end{array}$ & $\begin{array}{c}\text { Cumulative } \\
\text { eigenvalue }\end{array}$ & Total \% \\
\hline 1 & 10,5623 & 70,4153 & 10,5623 & 70,4153 \\
\hline 2 & 1,9426 & 12,9505 & 12,5049 & 83,3658 \\
\hline 3 & 1,3160 & 8,7732 & 13,8209 & 92,1391 \\
\hline
\end{tabular}




\begin{tabular}{|c|c|c|c|c|}
\hline № & Eigenvalue & $\begin{array}{c}\% \\
\text { of the total } \\
\text { variance }\end{array}$ & $\begin{array}{c}\text { Cumulative } \\
\text { eigenvalue }\end{array}$ & Total \% \\
\hline 4 & 0,6496 & 4,3307 & 14,4705 & 96,4697 \\
\hline 5 & 0,3444 & 2,2957 & 14,8148 & 98,7654 \\
\hline 6 & 0,1007 & 0,6710 & 14,9155 & 99,4364 \\
\hline 7 & 0,0492 & 0,3281 & 14,9647 & 99,7644 \\
\hline 8 & 0,0259 & 0,1724 & 14,9905 & 99,9368 \\
\hline 9 & 0,0050 & 0,0331 & 14,9955 & 99,9699 \\
\hline 10 & 0,0045 & 0,0301 & 15,0000 & 100,0000 \\
\hline
\end{tabular}

The first main component took the load of 12 indicators. Among them are GRP per capita; the level of employment of the population aged 15-72 years; the volume of paid services per capita; the number of own cars per 1000 people population; the total area of residential premises, on average per inhabitant and others. The first main component can be interpreted as «Coefficients that characterize the standard of living in the region». The second component is defined by two indicators. This is the share of unprofitable organizations and the ratio of average per capita income to the subsistence minimum. We interpret it as «Coefficients of financial capabilities of the region». The third main component contains only one indicator - the industrial production index. Let's call it the «Regional industry coefficient».

Next we calculate the integral assessment of investment attractiveness of the Volga Federal District of Russian Federation according to the weight coefficients:

$$
\begin{aligned}
& I A=\beta_{1} F_{1}+\beta_{2} F_{2}+\beta_{3} F_{3} \\
& F_{1}=0,095 x_{1}+0,053 x_{2}+0,107 x_{3}+0,026 x_{4}+ \\
& 0,086 x_{5}+0,102 x_{6}+0,115 x_{7}-0,106 x_{8}- \\
& 0,069 x_{9}+0,086 x_{10}+0,086 x_{11}-0,04 x_{12} \\
& 0,011 x_{13}+0,09 x_{14}+0,094 x_{15}
\end{aligned}
$$

$F_{2}=-0,017 x_{1}+0,08 x_{2}-0,008 x_{3}-0,404 x_{4}+$$$
0,048 x_{5}+0,02 x_{6}-0,032 x_{7}+0,321 x_{8}
$$$$
0,047 x_{9}+0,013 x_{10}-0,004 x_{11}-0,309 x_{12}+
$$$$
0,374 x_{13}-0,027 x_{14}-0,047 x_{15}
$$

$F_{3}=0,018 x_{1}-0,691 x_{2}-0,235 x_{3}+0,273 x_{4}+$ $0,044 x_{5}-0,11 x_{6}-0,24 x_{7}+0,104 x_{8}-$

$0,146 x_{9}+0,079 x_{10}+0,089 x_{11}-0,051 x_{12}+$

$0,134 x_{13}+0,071 x_{14}+0,047 x_{15}$

$\boldsymbol{\beta}_{\mathbf{i}}$ - share of the total variance of the i-th factor.

The final assessment of investment attractiveness of the Volga Federal District regions based on the indicators of 2018 is shown in table.4. The subjects are arranged in order of decreasing values of the level of investment attractiveness.

Table 4. Integrated assessment of investment attractiveness of Russian Volga Federal District regions

\begin{tabular}{|l|c|c|c|c|}
\hline & $\mathbf{F}_{\mathbf{1}}$ & $\mathbf{F}_{\mathbf{2}}$ & $\mathbf{F}_{\mathbf{3}}$ & IA \\
\hline $\begin{array}{l}\text { Republic of } \\
\text { Tatarstan }\end{array}$ & 0,69065 & 0,61295 & $-0,58509$ & $\mathbf{0 , 5 5 8 2 6}$ \\
\hline
\end{tabular}

\begin{tabular}{|l|c|c|c|c|}
\hline & $\mathbf{F}_{\mathbf{1}}$ & $\mathbf{F}_{\mathbf{2}}$ & $\mathbf{F}_{\mathbf{3}}$ & $\mathbf{I A}$ \\
\hline $\begin{array}{l}\text { Samara } \\
\text { region }\end{array}$ & 0,51758 & 0,01487 & $-0,31870$ & $\mathbf{0 , 3 6 7 2 9}$ \\
\hline $\begin{array}{l}\text { Nizhny } \\
\text { Novgorod } \\
\text { region }\end{array}$ & 0,45323 & 0,24763 & $-0,47211$ & $\mathbf{0 , 3 3 6 2 2}$ \\
\hline $\begin{array}{l}\text { Bashkortost } \\
\text { an }\end{array}$ & 0,46803 & 0,07059 & $-0,37830$ & $\mathbf{0 , 3 3 1 5 8}$ \\
\hline $\begin{array}{l}\text { Perm region } \\
\text { Mrenburg } \\
\text { region }\end{array}$ & 0,41439 & $-0,05557$ & $-0,29482$ & $\mathbf{0 , 2 8 0 8 1}$ \\
\hline $\begin{array}{l}\text { Republic of } \\
\text { Udmurtia }\end{array}$ & 0,33549 & $-0,06923$ & $-0,75793$ & $\mathbf{0 , 1 7 4 5 0}$ \\
\hline $\begin{array}{l}\text { Penza } \\
\text { region }\end{array}$ & 0,24123 & $-0,19816$ & $-0,22530$ & $\mathbf{0 , 1 3 5 0 5}$ \\
\hline $\begin{array}{l}\text { Saratov } \\
\text { region }\end{array}$ & 0,27225 & $-0,25538$ & $-0,41258$ & $\mathbf{0 , 1 3 2 8 8}$ \\
\hline $\begin{array}{l}\text { Ulyanovsk } \\
\text { region }\end{array}$ & 0,26850 & $-0,50392$ & $-0,08130$ & $\mathbf{0 , 1 2 6 6 3}$ \\
\hline $\begin{array}{l}\text { Kirov } \\
\text { region }\end{array}$ & 0,20308 & $-0,12959$ & $-0,34929$ & $\mathbf{0 , 1 0 3 7 2}$ \\
\hline $\begin{array}{l}\text { Republic of } \\
\text { Mordovia }\end{array}$ & 0,18072 & $-0,23440$ & $-0,24222$ & $\mathbf{0 , 0 8 2 1 0}$ \\
\hline $\begin{array}{l}\text { Chuvash } \\
\text { Republic }\end{array}$ & 0,07956 & $-0,03722$ & $-0,54337$ & $\mathbf{0 , 0 0 3 8 3}$ \\
\hline Republic of \\
\hline
\end{tabular}

In order to identify common features and similarities of regions in terms of investment attractiveness, we will conduct a cluster analysis. The purpose of cluster analysis is to group objects with similar characteristics into clusters.

Since in our case there is no information that any factor is more important for classification than others, we want to take into account the differences in each feature equally, so we will choose the usual Euclidean distance, formula (1), and Ward's method, which often gives fairly compact and well-separated clusters as a distance measure:

$$
\mathbf{d}_{\mathrm{ij}}=\sqrt{\sum_{\mathrm{k}=1}^{\mathrm{m}}\left(\mathbf{x}_{\mathrm{ik}}-\mathbf{x}_{\mathrm{jk}}\right)^{2}}
$$

The final composition of clusters is shown in table 5 .

Table 5. Cluster composition

\begin{tabular}{|c|c|c|}
\hline $\begin{array}{c}\text { Cluster } \\
\text { number }\end{array}$ & $\begin{array}{c}\text { Number } \\
\text { of objects } \\
\text { in the } \\
\text { cluster }\end{array}$ & Cluster composition \\
\hline
\end{tabular}




\begin{tabular}{|c|c|l|}
\hline $\begin{array}{c}\text { Cluster } \\
\text { number }\end{array}$ & $\begin{array}{c}\text { Number } \\
\text { of objects } \\
\text { in the } \\
\text { cluster }\end{array}$ & \multicolumn{1}{|c|}{ Cluster composition } \\
\hline 1 & 1 & Republic of Tatarstan \\
\hline 2 & 4 & $\begin{array}{l}\text { Samara region, Nizhny Novgorod } \\
\text { region, Bashkortostan, Perm region }\end{array}$ \\
\hline 3 & 3 & $\begin{array}{l}\text { Orenburg region, Ulyanovsk region, } \\
\text { Republic of Mari El }\end{array}$ \\
\hline 4 & 2 & $\begin{array}{l}\text { Republic of Udmurtia, Chuvash } \\
\text { Republic }\end{array}$ \\
\hline 5 & 4 & $\begin{array}{l}\text { Penza region, Saratov region, Kirov } \\
\text { region, Republic of Mordovia }\end{array}$ \\
\hline
\end{tabular}

To interpret the clusters, we plot the average values of the factors (Fig. 1).

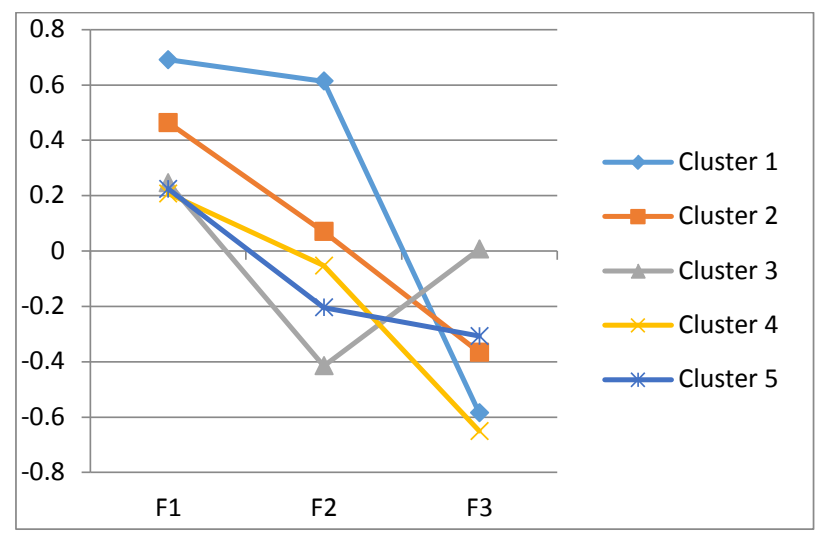

Fig. 1. Graph of average values of factors

\section{Conclusion}

The leader in terms of living standards and financial opportunities in the region is the first cluster, which includes the Republic of Tatarstan.

The second cluster has a fairly high standard of living in the regions, but the third factor has a negative value, which shows a low index of industrial production in the four regions included in the cluster.

The third cluster was the leader in the industrial production index among other clusters. But at the same time, it has the worst position on the second factor.

The fourth cluster is characterized by the standard of living in the region, but has the last position in almost all factors. Two of the three factor values are negative.

The fifth cluster does not stand out from the others. This cluster has average positions for all factors.

Hence, we can conclude that the regions included in clusters 1, 2 need to improve the level of industrial development in the region in order to increase investment attractiveness.

Regions included in 3, 4, 5 clusters have a large share of unprofitable organizations, as well as a low standard of living. It is possible that decreasing unprofitable organizations and improving the standard of living will lead to an increase in investment attractiveness in these regions.

\section{References}

1. A. Danilova, M. Monoyios, A. NG Mathematics and financial economics, 1, 13-38 (2009).

2. A.G. Kulagina, E.P. Mitrofanov, D.S. Fedyaeva Bulletin of Economics, law and sociology, 1, 26-30 (2014)

3. Ganju Jitendra, Lucas James American Statistician, 1, 5-11 (2000).

4. Kim Seong, Sun Dongchu Lifetime data analysis, 3, 251-269 (2000).

5. V.A. Arkhipova, A.G. Kulagina Economics and entrepreneurship, 2(103), 1186-1189 (2019) 